\title{
Changes in South African executive share-based remuneration
}

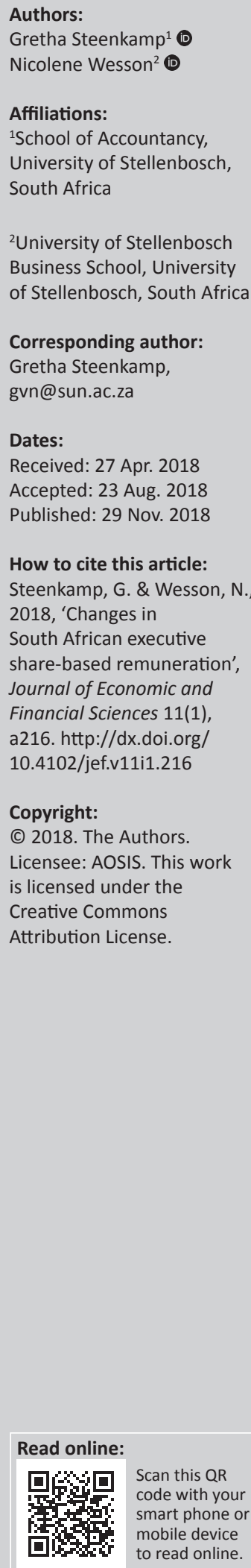

Orientation: Institutional theory proposes that companies respond to environmental factors (such as changes in accounting requirements and the economy) in order to gain or retain legitimacy. As such, environmental factors can affect executive remuneration paid by companies.

Research purpose: The purpose was to determine whether the implementation of International Financial Reporting Standard (IFRS) 2 as well as the financial recession affected the characteristics of share-based remuneration paid to South African executives.

Motivation for the study: Stakeholders should be aware of whether environmental factors influence business practice relating to share-based remuneration (especially in an emerging economy, such as South Africa, where international evidence might not be applicable).

Research design/approach and method: Share-based remuneration details of the chief executive officers of 28 South African listed companies were obtained for the period 2002-2009 (these dates were chosen to include both the effective date of IFRS 2 and the financial recession). Data were analysed (using analysis of variance and generalised estimating equalisation techniques) to determine whether there were statistically significant differences in the sharebased executive remuneration between the period before and after the effective date of IFRS 2, as well as before and during the financial recession.

Main findings: Share options usage decreased after the effective date of IFRS 2, and even further during the recession. Share-appreciation rights were increasingly used after the effective date of IFRS 2 and seemed to have replaced share options subsequent to the implementation of IFRS 2. The use of share purchase plans decreased during the recession and was replaced by performance shares. Performance vesting conditions were more prevalent in share-based remuneration schemes in the post-IFRS 2 period.

Practical/managerial implications: Shareholders and regulators should take cognisance of the fact that business practice in respect of share-based remuneration is affected by new accounting standards and the economy.

Contribution/value-add: This study addressed the knowledge gap in the literature regarding the effect of IFRS 2 and recession on executive share-based remuneration in emerging economies, and specifically in South Africa.

\section{Introduction}

\section{Setting}

\section{Key focus}

Directors' remuneration has become a contentious issue worldwide. The literature on directors' remuneration has pointed towards its excessiveness as well as the lack of correlation with company performance (Jensen \& Murphy 1990; Rankin 2010; Steyn 2015; Urson 2016). Concurrently, longterm share-based payments (SBPs), such as share options and performance shares, have increasingly been used as part of the remuneration package of executive directors (Murphy 2012). The rationale behind long-term share-based remuneration is that it aligns the objectives of executives with those of the shareholders, thereby minimising agency problems (Hall \& Murphy 2003). Using share-based remuneration might not only lead to increase in directors' remuneration but also increased correlation with company performance. As long-term share-based remuneration plays an increasingly larger role in executive remuneration, it becomes important to understand such payments and the factors that influence the characteristics thereof. Steyn (2015), however, indicated that, in South Africa, most previous studies on directors' remuneration focus on guaranteed pay as well as short-term incentives, but neglect long-term share-based remuneration. This might be because of the complexity of the instruments used in long-term share-based schemes and the lack of 
comprehensive and detailed disclosure in the annual financial statements (AFS) in this regard (Urson 2016).

\section{Background}

Share-based remuneration to executives can be defined as remuneration received by executives of which the value changes in response to the company share price (International Accounting Standards Board [IASB] 2004). Two types of sharebased remuneration exist: those that are equity-settled (eventually settled by the company issuing shares) and those that are cash-settled (where the amount owed is paid out in cash, but determined with reference to the share price) (IASB 2004). Before the effective date of International Financial Reporting Standard (IFRS) 2 on SBPs, equity-settled SBPs were not recognised as an expense in the AFS of the company granting them, while cash-settled SBPs were recorded as an expense (Pretorius \& De Villiers 2013). In the 1990s and early 2000s (before the effective date of IFRS 2), equity-settled share options were the most common share-based remuneration being used, probably owing to share options not causing an expense in the AFS (Murphy 2012). After the effective date of IFRS 2 (which was financial years ending on or after 31 December 2005), all share-based remuneration should now be recognised as an expense (IASB 2004). In many post-implementation studies, it has been found that the mandatory expensing of share options led to a decrease in their popularity after the effective date, with a corresponding increase in the usage of share-appreciation rights (SARs) as well as performance shares (Balsam, O'Keefe \& Wiedemer 2007; Brown \& Lee 2011).

The global financial recession of 2008/2009 had an impact on many aspects of the business world. It can be expected that the usage of share-based remuneration was also affected by the recession, as executive remuneration receives more attention from shareholders in financial crisis (Scholtz \& Smit 2012). Excessive and inappropriate executive remuneration was also blamed as causal in the recession, and companies might have adjusted their remuneration strategy in response (Avallone, Quagli \& Ramassa 2014), by changing from appreciation-based schemes (such as share options and share-appreciation rights) to full quantum schemes (such as restricted and performance shares) (Rankin 2010). Avallone et al. (2014) also found that companies granted less sharebased remuneration during the financial crisis.

Murphy (2012) proposed that environmental factors (such as accounting requirements and economic conditions) play a role in determining both the size and structure of executive remuneration. This can be seen as akin to institutional theory, which proposes that companies are caught in a complex interplay between optimising their technical operations and being seen as legitimate in the changing context in which they operate (DiMaggio \& Powell 1983; Suddaby 2010), for example by changing their business practices regarding share-based remuneration in response to pressures from the greater environment (Bruce, Buck \& Main 2005). With institutional theory as background, it is considered important that shareholders and other stakeholders of companies know whether the characteristics of executive share-based remuneration have been influenced by the adoption of IFRS 2 as well as the financial recession. This is especially relevant given that the IASB was reassessing IFRS 2 during the past few years and assessing whether major adjustments to the methodology relating to equity-settled SBPs are warranted (IASB 2016). If the initial adoption of IFRS 2 had an effect on business practice, then any major adjustments to IFRS 2 could also similarly affect the characteristics of share-based remuneration being employed.

In the South African context, with its large income inequality, there is an increased necessity to understand the factors that determine and influence executive remuneration (Steyn 2015). Effective executive remuneration can also lead to increased corporate performance and job creation - which is sorely needed in the economy (Steyn 2015). South Africa is an emerging economy, but has a well-developed financial sector (Wesson et al. 2017) and all listed companies have to apply IFRS 2, according to the Johannesburg Stock Exchange (JSE) listing requirements (JSE 2017). The effect of the global recession was less pronounced in South Africa, as a result of strict banking regulations, which adds to the reasons why South Africa is an interesting setting to study the issue at hand (Baxter 2008).

No study similar to the present study has yet been performed in South Africa. Mavrodinov (2012) studied South African share-based remuneration practices in 2011 and found that SAR and performance share schemes were employed more often than share options (which was the primary type of scheme in use before the effective date of IFRS 2). The shift between share options and other types of schemes occurred somewhere between the effective date of IFRS 2 and 2011, but the exact timing and reason for the shift are unknown, which serves as motivation for the present study.

\section{Objective}

The objective of this study was to determine whether the implementation of IFRS 2 as well as the financial recession affected the characteristics of share-based remuneration paid to South African executives. Institutional theory, and specifically legitimacy, provides a theoretical base for the study.

The following research questions were developed:

- Is there a difference in the characteristics of the sharebased remuneration paid to South African executives before and after the implementation of IFRS 2?

- Is there a difference in the characteristics of the sharebased remuneration paid to South African executives before and during the recession?

\section{Contribution to the field}

This study adds to the global debate on executive share-based remuneration, and specifically proposes (based on institutional theory) that changes in accounting requirements (the implementation of IFRS 2) affect the characteristics of share- 
based remuneration employed by companies in practice. This has worldwide significance because of the IASB recently reassessing the accounting requirements for SBPs. If the initial adoption of IFRS 2 had an effect on business practice, then substantial amendments could likewise be expected to influence the characteristics of share-based remuneration to executives.

Current literature from developed economies points towards the effect of the adoption of IFRS 2 and the financial recession on the characteristics of share-based remuneration (Avallone et al. 2014; Balsam et al. 2007; Brown \& Lee 2011; Rankin 2010), but no similar studies have been performed in emerging economies. Share-based remuneration in emerging economies tends to be dissimilar to those in developed economies because of differing corporate governance requirements (Sahakiants \& Festing 2016). South Africa, specifically, is an interesting setting for the study, as South Africa is an emerging economy, but has a well-developed financial sector and stock exchange (Wesson et al. 2017). This study addressed the knowledge gap in the literature regarding the effect of IFRS 2 and recession on executive share-based remuneration in emerging economies, and specifically in South Africa.

\section{Literature review}

A share-based transaction is one where goods or services are received by an entity in exchange for its own equity instruments or cash, and the payment is based on the share price of the equity instruments of the entity (IASB 2004). Common forms of SBPs include share options, SARs and performance shares (Mavrodinov 2012). Share-based payments are mostly settled in equity, but can also be settled in cash. Share-based payments can be made to both employees and non-employees, but this study focuses solely on SBPs granted to executives as part of remuneration. The term SBP is used in this study to refer to any SBP, whether to an employee or non-employee, while the term share-based remuneration is used to refer solely to those SBPs paid as remuneration to employees, specifically executives.

\section{Share-based remuneration to executives}

To understand share-based remuneration to executives, one needs to consider the different dates applicable in the life of such an incentive. On the grant date, the incentives are contractually promised to the employees (IASB 2004). On the vesting date, following a vesting period in which certain vesting conditions need to be satisfied, the executive becomes entitled to the benefit (Massie, Collier \& Crotty 2014). The vesting conditions include both requirements to remain in service of the company, as well as performance conditions, such as reaching earnings per share (EPS) targets (Mavrodinov 2012). On the vesting date, the incentive is either exercised immediately or during a stipulated exercise period (Massie et al. 2014).

Share options: Initially share options were the predominant type of share-based incentive offered to executives (Mavrodinov 2012). The prevalence in the 1990s and early 2000s can be ascribed to share options not resulting in a cash outflow and not being recognised for accounting purposes prior to 2006 (the effective date of IFRS 2) (Hall \& Murphy 2003). During the bull market reigning at the time, executives made extensive gains on the exercise of such share options (Mavrodinov 2012). The downside to share options is the dilution in ownership it causes to existing shareholders (Mavrodinov 2012). After the effective date of IFRS 2, share options granted to executives had to be recognised as an expense and equity reserve, based on the grant date fair value of the share option (IASB 2004).

Share options granted to executives are call options (options that entitle the holder thereof to buy shares) written by the employing company on its own shares (Hall \& Murphy 2003). A share option has value for the employee if it is 'in the money' on the exercise date - meaning that the share can be purchased at an exercise price less than the prevailing market price (Steyn 2015). Commonly the executive has to work for a vesting period of 3-5 years, after which the share option vests (Mavrodinov 2012). The holder (the executive) can then exercise the share option during a lengthy exercise period, by paying the exercise price (Mavrodinov 2012). The exercise price is commonly the share price on grant date, which then effectively remunerates the executive for the increase in the share price between the grant date and the exercise date (Mavrodinov 2012). Share options granted to executives are usually settled by physically issuing the shares, but could also be net settled in cash or shares (Mavrodinov 2012). Executive share options are different from normal traded options owing to their required vesting period, the length of the exercise period and the fact that they cannot be transferred or sold (Hall \& Murphy 2003).

SARs: Share-appreciation rights are effectively cash-settled share options. The holder of a SAR is entitled to a cash payment equal to the increase in the share price from grant date to exercise date (Massie et al. 2014). Similar to share options, SARs vest after the completion of a service period. The advantage of a SAR from the company's perspective (when compared to a share option) is that no dilution in ownership occurs as no shares are issued (Mavrodinov 2012). The disadvantages include the cash outflow required, as well as the fact that annual fair valuing of the cash-settled instrument granted is required by IFRS 2 (in contrast, equitysettled SBPs to employees are measured at the grant date fair value throughout the vesting period) (IASB 2004). As a result of the annual fair valuing, SARs cause a larger accounting expense (than share options) in a bull market.

Share purchase plans: A plan where a company facilitates the purchase of company shares by executives through granting of loans is referred to as a share purchase plan (Mavrodinov 2012). The executive buys a share in the company at the prevailing market price on the grant date, but only has to pay this purchase price at a later stage (purchase price is treated as an outstanding loan in the interim) (Mavrodinov 2012). The shares purchased are held in trust until the purchase price has been paid. The gain that an executive stands to make is the increase in share price 
between grant date and the date of the repayment of the loan and, as such, share purchase plans are recorded as share options under IFRS 2 (Deloitte 2005). A share purchase plan exposes executives to downside risk as they still have to repay the loan if the share price falls (Mavrodinov 2012).

Performance shares: Under a performance share plan the executive is granted shares at no cost, which the executive receives after the completion of a vesting period (Massie et al. 2014). During the vesting period, the executive must stay in service of the company and, furthermore, targets that are focused on the individual executive and/or the entire company must be achieved (Steyn 2015). In contrast to share options and SARs, which are classified as appreciation schemes, performance shares are full quantum schemes, meaning that executives share in both the benefit of the increase in the share price (upside gain) and the risk of the decrease in the share price (downside risk) (Mavrodinov 2012). Researchers have been advocating the use of full quantum schemes because these are more effective than appreciation schemes in aligning shareholders' and executives' interests (as executives who participate in full quantum schemes are exposed to the same risks as the shareholders) (Mavrodinov 2012).

\section{Theoretical perspectives on share-based remuneration to executives}

Many theories are used to explain and understand executive remuneration, particularly share-based remuneration. The most prominent theory is that of agency theory (Baeten, Balkin \& Van den Berghe 2011). The agency theory and optimal contracting theory propose that financial incentives (and specifically share-based remuneration) are optimal in aligning the interests of the executives with those of the shareholders and reduce agency problems (Hall \& Murphy 2003). This theory proposes that company performance and shareholder value should be highly correlated, but empirical results in this respect have been inconclusive (Baeten et al. 2011). In contrast to the agency theory, the managerial power theory views the current structuring of executive remuneration as suboptimal as it constitutes the extraction of excessive 'rents' from the company by directors with improper power (Bebchuk, Fried \& Walker 2002).

Past studies using agency or managerial power theories have failed to completely explain the current state of executive share-based remuneration, especially when companies in different countries are considered (Bruce et al. 2005). Another complementary theory that can be used to explain the characteristics of executive share-based remuneration is institutional theory, which is especially relevant in emerging economies such as South Africa (Sahakiants \& Festing 2016). Under institutional theory, the external environment in which the company operates plays a role in the internal functioning of the company (Hoque 2006) and possibly also in how it structures its share-based remuneration (Bruce et al. 2005). New accounting requirements and the general economic environment could influence the structuring of executive share-based remuneration (Sahakiants \& Festing 2016) in order to provide legitimacy to the company (Deephouse \& Suchman 2010).

Institutional theory was developed in the sociology field, and it studies how an 'institution' (way of doing things) becomes established and then changes again (Hoque 2006). On the one hand, institutional theory has to do with all players in a certain field conforming to a certain institution, while on the other hand, it studies the rise and fall of institutions (Hoque 2006). In organisational institutionalism (i.e. the study of institutional theory in the context of organisations and companies), companies are seen as players within the institutional field. An example of an institution could be companies 'remunerating executives in share options' if this becomes the established way of structuring share-based remuneration.

Although, the primary function of companies is to attain technical goals (e.g. produce and sell products to create profit for the shareholders) (Suddaby 2010), companies need to support the technical goals by being seen as 'legitimate' in the environment in which they operate (Bruce et al. 2005). Legitimacy is achieved when a company is seen to conform to society's regulations and norms (Deephouse \& Suchman 2010). A company that is deemed to be legitimate can pursue its technical goals with greater ease and has a greater chance of survival (Deephouse \& Suchman 2010). To evaluate a company's legitimacy its corporate actions are evaluated (Deephouse \& Suchman 2010), of which executive remuneration is a prime example (Bruce et al. 2005). This search for legitimacy is one of the cornerstones of organisational institutionalism (Deephouse \& Suchman 2010) and drives companies to respond to the external pressures exerted on it (such as changing accounting rules and the economic conditions) (DiMaggio \& Powell 1983).

When considering share-based remuneration specifically, it would seem that the practices of the developed nations are being adapted by emerging economies, and that the two environments, therefore, differ in terms of the characteristics of executive share-based remuneration (Bruce et al. 2005). On the other hand, companies in a certain local environment (such as South Africa) that are exposed to similar external pressures would be expected to converge towards homogeneity (DiMaggio \& Powell 1983). DiMaggio and Powell (1983) point out three types of pressures that lead to this convergence (also called isomorphism): coercive (which come from legal, corporate governance and other requirements), mimetic (because of companies copying what the market leaders are doing) and normative (because of outsourcing the matter to professional firms using standard principles). All three of the pressures mentioned could influence South African share-based remuneration.

In conclusion, South African executive share-based remuneration would be shaped by the institutions surrounding it, adherence to which allows companies to be deemed legitimate in terms of their share-based remuneration 
practices. For example, one would expect companies to decrease share-based remuneration in times of financial recession, to retain legitimacy in the eyes of society.

\section{The development of International Financial Reporting Standard 2}

International Financial Reporting Standard 2 was developed by the IASB to prescribe the accounting treatment of SBPs in the AFS (Giner \& Arce 2012). Before IFRS 2 was developed, most SBPs were merely disclosed, but IFRS 2 requires the recognition of all SBPs as an expense and equity/liability (IASB 2004). When IFRS 2 was issued in 2004 the predominant SBP type was share options granted to directors as remuneration, which was not expensed or recognised in the AFS before IFRS 2 became effective (Atan, Jasni \& Shahwan 2010; Pretorius \& De Villiers 2013). Although equity-settled SBPs (such as share options) do not cause a cash outflow, a dilution in the value attributable to current shareholders does occur (Pretorius \& De Villiers 2013), and goods and services are received that should be expensed to decrease earnings (Giner \& Arce 2012). International Financial Reporting Standard 2 was effective internationally and in South Africa for reporting periods ending on or after 31 December 2005 (IASB n.d.). International Financial Reporting Standard 2 is aligned to the American accounting standard dealing with SBPs in many respects (Giner \& Arce 2012).

International Financial Reporting Standard 2 divides SBPs into three categories, namely equity-settled, cash-settled and choice-settled (IASB 2004). The most common type is equitysettled, which is when share options or shares will be given in exchange for goods and services (IASB 2004). Cash-settled SBPs will be settled in cash, but the value of that payment will vary based on the share price of the company (IASB 2004). Choice-settled SBPs give either the entity or the counterparty the choice of how it will be settled at the exercise date (IASB 2004) Equity-settled and cash-settled SBPs have contrasting accounting models. Cash-settled SBPs are recorded similarly to provisions and financial liabilities at the value that is expected to be paid (i.e. based on the fair value of the instrument at reporting date) (IASB 2004). Equitysettled SBPs are, however, measured uniquely - and are based on the principle that equity should not be remeasured (IASB 2015b). If the equity-settled SBP is with a nonemployee, then the entity should account for the transaction using the direct method (i.e. based on the fair value of the goods or services received on the date of the transaction) (IASB 2004). This is consistent with a company issuing shares for consideration, which is recognised at the value received in exchange for the shares and is well-accepted as being consistent with the IASB's Conceptual Framework (IASB 2015b). Most equity-settled, share-based transactions are, however, transactions with employees of the entity (including directors) that are recognised using the indirect method (i.e. based on the fair value of the equity instruments granted, measured on the grant date) (IASB 2004). According to a recent study by the IASB, the majority of the issues with IFRS 2 centre on this principle of recognising the expense based on the grant date fair value and not adjusting for subsequent changes in the fair value of the equity instruments granted (IASB 2015b). This leads to different accounting models for equity and cash-settled SBPs, and the expense relating to an equity-settled SBP is potentially recognised at an amount different from the actual value accruing to the employee.

\section{Effects of International Financial Reporting Standard 2 and the financial recession on share-based remuneration}

International Financial Reporting Standard 2 was a controversial standard when issued, owing largely to the fact that the recipients of SBPs are mostly company directors and that their remuneration is scrutinised at length (Giner \& Arce 2012; IASB 2015b). Not expensing share-based remuneration to directors can cause corporate governance problems (Pretorius \& De Villiers 2013) and can also artificially increase the popularity of share-based remuneration (Avallone et al. 2014). The earnings volatility accompanying the expensing of share-based remuneration under IFRS 2 could have led to a decrease in the overall usage of share-based remuneration, an amendment to the type of arrangements being employed or an increase in the use of performance-linked vesting conditions (Fisher \& Wise 2006). Fisher and Wise (2006) commented on the importance of understanding the effect of the implementation of IFRS 2 on business practice to ensure appropriate governance of share-based remuneration.

A South African study on periods commencing subsequent to the effective date of IFRS 2 found that EPS showed a statistically significant decrease during the post-IFRS 2 period (Pretorius \& De Villiers 2013). The average rand-value of the IFRS 2 expense reported in profit-or-loss decreased over the period 2006-2009, although the number of companies reporting an expense for SBPs increased (Pretorius \& De Villiers 2013). Pretorius and De Villiers (2013) mentioned that the expensing of equity-settled SBPs could cause a decrease in the popularity of share options and an increase in SARs, but that further research would be required to determine whether IFRS 2 in fact resulted in a change of share-based remuneration types. Mavrodinov (2012) analysed the sharebased remuneration paid to executives by 50 large JSE-listed companies at the end of 2011 and found that share option schemes were employed by fewer companies than those using SAR and performance share schemes. Owing to the Mavrodinov (2012) study being performed at a single point in time (2011), it remains uncertain when exactly the decrease in share options and increase in SARs and performance shares had occurred. This date occurred somewhere between the effective date of IFRS 2 and 2011 (when the Mavrodinov study was carried out), and might be related to the effective date of IFRS 2 or the financial recession of 2008/2009.

In Australian and American studies, it was found that the use of share options diminished after the effective date of IFRS 2 (Balsam et al. 2007; Brown \& Lee 2011; Pretorius \& De Villiers 2013) with a corresponding increase in restricted shares (Carter, Lynch \& Tuna 2007), while in an Italian study the effective date of IFRS 2 did not significantly affect the number 
of share options being granted (Avallone et al. 2014). In Australia, it was found that the implementation of IFRS 2 affected the length of the vesting period of share options, but did not affect the usage of performance vesting conditions (Qu et al. 2016). Contrastingly, in the USA, Bettis et al. (2015) found that performance vesting conditions increased after the effective date of FAS123R (the US equivalent of IFRS 2).

Avallone et al. (2014) found that Italian companies were less likely to grant share options during the recession. In Australia, it was found that in 2009 (when compared to the period 20062008) cash payments, such as salary and annual bonus, made up a greater portion of executive pay than long-term equitysettled schemes (Rankin 2010). This change in the structuring of executive pay was ascribed to the recession (Rankin 2010). Although the use of equity-settled schemes decreased in 2009, companies were more likely in 2009 to employ full quantum schemes (when comparing 2009 to the period 2006-2008) denoting a shift in the type of scheme being employed (Rankin 2010). During and after the recession, companies were more likely to change their pay structure in response to new regulatory requirements (Barontini et al. 2013). In South Africa, new corporate governance regulations were promulgated in the third King Report, but were only effective from 2010 onwards, and, therefore, did not affect the periods covered in the present study.

\section{International Financial Reporting Standard 2 under review by International Accounting Standards Board}

The expensing of SBPs seems to be, in general, a wellaccepted practice of recognising the goods and services received by the entity (IASB 2015b). During 2012 the IASB identified IFRS 2 as an accounting standard that warrants further research, owing to its complexity and the large number of interpretation requests received by the IASB that were referred to the IFRS Interpretations Committee (previously called the IFRIC) (IASB 2015a) (referred to as the 'IFRS 2 research project by IASB'). During the IFRS 2 research project by the IASB (which stretched over the period 2012-2016), it was found that the main problem with the current IFRS 2 is using the grant date fair value to account for equity-settled SBPs with employees. Four alternative classification and measurement approaches for equity-settled SBPs were proposed in the IFRS 2 research project by the IASB (2015b).

In 2016, the IASB decided to temporarily abandon the IFRS 2 research project launched in 2012 owing to other issues being more important and IFRS 2 being operationally effective even with its complexities (IASB 2016). It was suggested that the complexity of the standard could not be reduced without revising the principle of measuring equity-settled SBPs to employees using the grant date fair value (IASB 2016). The IASB was not inclined to change the grant date fair value measurement principle before the outcome of the ongoing IASB research project on financial instruments with characteristics of equity (FICE) was known (IASB 2016). The FICE project team was drafting a discussion paper during 2017 (with no clear final effective date of the final amendments), but the final outcome of the FICE project will be used to determine whether further research on IFRS 2 is necessary (IASB 2016).

\section{Research methodology Overall research methodology}

This study is a social research paper with a combination of theoretical and empirical elements. It falls in the positivistic paradigm, focusing on what can be observed and measured. The research approach is quantitative, using longitudinal secondary data obtained from the IRESS financial database as well as AFS. The research questions are descriptive - aiming to describe the characteristics of share-based remuneration that executive directors received before and after the implementation of IFRS 2 as well as before and during the recession. Once the characteristics are described, a conclusion is drawn on whether the implementation of IFRS 2 in South Africa and the recession seem to have altered the characteristics of share-based remuneration.

\section{Detailed research methodology}

\section{Sample selection}

Only JSE-listed companies were selected to be part of the sample, as JSE-listed companies are required to apply IFRS 2 in their AFS. Some data items regarding share-based remuneration to executive directors of South African listed companies are available electronically on the IRESS database. However, these items have to be extracted per director per year and the process is time-consuming. Furthermore, the data captured in this way are incomplete or inaccurate in some respects and have to be updated on the basis of the information contained in the AFS. Given the lengthy process of obtaining accurate data on share-based remuneration described above, a limited sample was selected. Firstly, chief executive officers (CEOs) were selected as proxy for executive directors as all executives are usually remunerated similarly, with CEOs just being paid higher amounts or via a greater number of instruments. Chief executive officers also play a leading role in the company. Other global and local studies have applied similar proxies for executive remuneration (Steyn 2015; Urson 2016). Secondly, only 33 companies were selected (which keeps the sample small enough to allow efficient data collection, but large enough for thorough statistical analysis), representing a wide range of JSE industries and sectors (excluding those in the Basic Resources and Financials sectors, which are highly regulated) and covering small, medium and large listed companies. The 33 companies were reduced to 28 because one of the sampled companies did not have a CEO (only non-executive directors) and four others were not listed for the entire period. A list of the companies selected is presented in Appendix 1.

\section{Period for which data were collected}

Data were collected for the period 2002 (when disclosure in the AFS was first done per director) to 2009. These dates were chosen to include both the effective date of IFRS 2 and the 
financial recession of 2008/2009. Firstly, IFRS 2 implementation had to be considered, and because the implementation of IFRS 2 occurred at a specific point in time, a typical beforeafter study was implemented for this element. The effective date of IFRS 2 in South Africa was year-ends ending on or after 31 December 2005. As such, the end of 2005 or beginning of 2006 was seen as the turning point for this research. Sufficient data points before and after the date had to be collected; hence, it was decided to study four years prior to this point (2002 to 2005) and four years after (2006 to 2009).

Secondly, the financial recession had to be considered. The financial recession encompassed a time period (and not a specific point in time) and the business practices during this period were of interest in the study. As such, it was decided to compare the period of time after IFRS 2 was implemented, but before the recession (2006 and 2007) to the time period during the recession (2008 and 2009). The period covered by the present study corresponds to the period covered by Avallone et al. (2014), who addressed similar research questions.

\section{Process of data collection}

After identifying the CEO of the company from the AFS for each of the company years to be studied, the share-based remuneration data were extracted from the IRESS database. These data were analysed and all obvious inaccuracies and incompleteness were identified (Steenkamp \& Wesson 2018). In the case of inaccuracies and incompleteness, these were updated and corrected based on the information contained in the AFS (Steenkamp \& Wesson 2018). The data captured included the name of the CEO, the year, the guaranteed pay, the number of schemes employed, the type of share-based remuneration (share options, SARs, contingent shares, etc.), number of instruments granted, vesting conditions applicable and number of instruments outstanding at year-end.

\section{Data analysis}

The data for the period 2002-2005 (pre-IFRS 2) were combined, as were the data for the period 2006-2009 (postIFRS 2). Descriptive statistics were performed for the two data sets, and later these two were compared to evaluate whether they differed significantly using statistical tests, including mixed model analysis of variance (ANOVA) and generalised estimating equalisation (GEE). Analysis of variance and generalised estimating equalisation tests were employed as these tests were best suited to answer the research question, given the characteristics of the data collected. The same process was performed for 2006 and 2007 (the pre-recession period) compared to 2008 and 2009 (during the recession). To evaluate statistical significance, a 5\% level of significance was applied $(p<0.05)$.

\section{Ethical considerations}

Ethical standards and procedures were adhered to in conducting this research. Ethical clearance was obtained from the Stellenbosch University Research Ethics Committee (reference number USB-2017-1814).

\section{Results}

\section{Comparing the period before and after the effective date of International Financial Reporting Standard 2}

The period before the effective date of IFRS 2 was 2002-2005 (4 years) and is referred to as the pre-IFRS 2 period, while the period after the effective date of IFRS 2 was also 4 years (2006 to 2009) and is referred to as the post-IFRS 2 period. Descriptive statistics (the mean and median for each variable in the pre- and post-IFRS 2 period) can be observed in Table 1. Both the mean and median figures are provided in Table 1 , as

TABLE 1: Descriptive statistics on pre-International Financial Reporting Standard 2 and post-International Financial Reporting Standard 2 periods.

\begin{tabular}{|c|c|c|c|c|}
\hline \multirow[t]{2}{*}{ Research variable } & \multicolumn{2}{|c|}{ Mean } & \multicolumn{2}{|c|}{ Median } \\
\hline & Pre-IFRS 2 (2002-2005) & Post-IFRS 2 (2006-2009) & Pre-IFRS 2 (2002-2005) & Post-IFRS 2 (2006-2009) \\
\hline \multicolumn{5}{|l|}{ General } \\
\hline Guaranteed pay (inflation adjusted) & R2 757591 & R3 914681 & R2 514192 & R3 342953 \\
\hline Short-term incentives (inflation adjusted) & R1 850337 & R2 558444 & R696 731 & R1 711990 \\
\hline Number of schemes employed & 0.73 & 1.22 & 1.00 & 1.00 \\
\hline \multicolumn{5}{|l|}{ Share options } \\
\hline Number granted & 260079 & 297624 & 0 & 0 \\
\hline Number of closing balance & 2291257 & 1540900 & 1164220 & 780648 \\
\hline \multicolumn{5}{|l|}{ SARs } \\
\hline Vesting period & 3 years & 3.8 years & 3 years & 3 years \\
\hline Number granted & 750000 & 276900 & 750000 & 110400 \\
\hline Number of closing balance & 750000 & 711264 & 750000 & 604548 \\
\hline \multicolumn{5}{|l|}{ Share purchase plan } \\
\hline Number granted & 302406 & 158534 & 278979 & 300000 \\
\hline Number of closing balance & 4358520 & 1881221 & 939519 & 300000 \\
\hline \multicolumn{5}{|l|}{ Performance shares } \\
\hline Vesting period & $\mathrm{N} / \mathrm{A}$ & 3.29 years & N/A & 3 years \\
\hline Number granted & 0 & 186111 & 0 & 196004 \\
\hline Number of closing balance & 0 & 246845 & 0 & 196004 \\
\hline
\end{tabular}

IFRS, International Financial Reporting Standard; SARs, share-appreciation rights. 
the mean and median figures are known to be quite different when working with directors' remuneration owing to many zeros or lower figures with a limited number of very large outliers (Murphy 2012).

The guaranteed pay includes salary and other benefits while the short-term incentives are the annual bonuses and other annual incentives. Both the guaranteed pay and the shortterm incentives were adjusted for inflation to be expressed in a 2009-equivalent value. Even after inflation adjustment both the guaranteed pay and the short-term incentives were higher in the post-IFRS 2 period, in line with the general notion that executive pay has been increasing in real terms. The number of schemes employed by companies in the sample increased in the post-IFRS 2 period. Considering the fact that guaranteed pay, short-term incentives as well as the use of share-based schemes increased in the post-IFRS 2 period, there does not seem to be any indication of rebalancing taking place between the components of remuneration (e.g. where the share-based remuneration is increasing, but shortterm incentives are decreasing at the same time).

The number of schemes increased mostly because of the granting of SARs and performance shares in the post-IFRS 2 period - with only a single occurrence of a SAR being granted in the pre-IFRS 2 period. The increase in the number of schemes being utilised in the post-IFRS 2 period signals a change in the type of share-based remuneration being granted, as the previously granted option schemes still had to complete their vesting and exercise periods, while new scheme types (performance shares and SARs) were being granted. These findings correspond to global evidence in this regard: that IFRS 2 adoption caused a decrease in share options grants. In South Africa, specifically, the options seem to have been exchanged for SARs (as was predicted in Pretorius \& De Villiers 2013).

In line with previous research (Murphy 2012), the median guaranteed pay and median short-term incentives were lower than their respective means, while the median number of share options granted fell to zero (indicating that some companies grant large numbers of share options, but most grant none). The rest of the data showed that, although the median was mostly lower than the mean, the trend between pre- and post-IFRS 2 remained largely unchanged.

The measures on which the performance vesting conditions of the different schemes were based in the pre- and post-IFRS 2 period are presented in Table 2 .

A definite increase in the usage of performance vesting conditions can be noted in the post-IFRS 2 period, with conditions based on meeting certain share price, total shareholders' return (TSR) and EPS targets being the most common. Share-appreciation rights were increasingly used in the post-IFRS2 period, and after the effective date of IFRS 2 it became more common for SARs to have performance vesting conditions attached. Performance shares (which, as the name suggests, implicitly have performance vesting conditions
TABLE 2: Performance vesting conditions of the different schemes.

\begin{tabular}{lll}
\hline Scheme type & Pre-IFRS 2 (2002 to 2005) & Post-IFRS 2 (2006 to 2009) \\
\hline Share options & None, share price & None, share price \\
SARs & None & None, unknown, EPS, TSR, others \\
Share purchase plan & None & None \\
Performance shares & N/A & Unknown, EPS, TSR \\
\hline
\end{tabular}

IFRS, International Financial Reporting Standard; SARs, share-appreciation rights; EPS, earnings per share; TSR, total shareholders' return.

TABLE 3: Differences between the pre-International Financial Reporting Standard 2 and post-International Financial Reporting Standard 2 period.

\begin{tabular}{|c|c|c|c|}
\hline Research variable & $\begin{array}{c}F \text {-test or } \\
\text { Wald-test value }\end{array}$ & $p$ & Interpretation \\
\hline $\begin{array}{l}\text { Guaranteed pay } \\
\text { (inflation adjusted)* }\end{array}$ & $F=61.7$ & $<0.01$ & $\begin{array}{l}\text { Significantly higher in } \\
\text { post-period }\end{array}$ \\
\hline $\begin{array}{l}\text { Short-term incentives } \\
\text { (inflation adjusted) }\end{array}$ & $F=6.7$ & 0.01 & $\begin{array}{l}\text { Significantly higher in } \\
\text { post-period }\end{array}$ \\
\hline $\begin{array}{l}\text { Number of schemes } \\
\text { employed }\end{array}$ & $F=46.1$ & $<0.01$ & $\begin{array}{l}\text { Significantly more } \\
\text { schemes in post-period }\end{array}$ \\
\hline $\begin{array}{l}\text { Whether a share option } \\
\text { scheme was used }\end{array}$ & Wald $=0.16$ & 0.69 & $\begin{array}{l}\text { No significant difference } \\
\text { between pre- and } \\
\text { post-period }\end{array}$ \\
\hline $\begin{array}{l}\text { Number of share } \\
\text { options: granted* }\end{array}$ & $F=2.1$ & 0.15 & $\begin{array}{l}\text { No significant difference } \\
\text { between pre- and } \\
\text { post-period }\end{array}$ \\
\hline $\begin{array}{l}\text { Number of share } \\
\text { options: closing balance* }\end{array}$ & $F=16.8$ & $<0.01$ & $\begin{array}{l}\text { Significantly fewer share } \\
\text { options outstanding in } \\
\text { post-period }\end{array}$ \\
\hline $\begin{array}{l}\text { Whether a SAR plan } \\
\text { was used }\end{array}$ & Wald $=14.9$ & $<0.01$ & $\begin{array}{l}\text { Significantly more SARs } \\
\text { schemes in use in } \\
\text { post-period }\end{array}$ \\
\hline $\begin{array}{l}\text { Whether a share purchase } \\
\text { plan was used }\end{array}$ & Wald $=1.7$ & 0.19 & $\begin{array}{l}\text { No significant difference } \\
\text { between pre- and } \\
\text { post-period }\end{array}$ \\
\hline $\begin{array}{l}\text { Number of share purchase } \\
\text { plans: granted }\end{array}$ & $F=0.6$ & 0.47 & $\begin{array}{l}\text { No significant difference } \\
\text { between pre- and } \\
\text { post-period }\end{array}$ \\
\hline $\begin{array}{l}\text { Number of share purchase } \\
\text { plans: closing balance* }\end{array}$ & $F=1.1$ & 0.31 & $\begin{array}{l}\text { No significant difference } \\
\text { between pre- and } \\
\text { post-period }\end{array}$ \\
\hline
\end{tabular}

SARs, share-appreciation rights.

*, A BoxCox transformation was applied to this data (as not normally distributed).

attached) were also employed for the first time in the post-IFRS 2 period. The finding of the present study on the increased usage of performance vesting conditions subsequent to the effective date of IFRS 2 corresponds to previous research from the USA (where Bettis et al. [2015] found that performance vesting conditions became more prominent after the implementation of FAS123R - the American version of IFRS 2). However, this finding of the present study differs from previous research from Australia in which Qu et al. (2016) found no increase in the usage of performance vesting conditions after the effective date of IFRS 2.

To evaluate whether the pre- and post-IFRS 2 period differed significantly, analysis of variance tests were performed (ANOVA and GEE). A BoxCox transformation was applied for data that were not normally distributed (indicated by an asterisk (*) in Table 3). The results of the comparison of preIFRS 2 and post-IFRS 2 period can be observed in Table 3. Some of the variables (listed in Table 1) had too few data points and, therefore, could not be analysed. Table 3 only includes the variables with enough data points available.

Statistical analysis confirmed that there was a significant increase in guaranteed pay as well as short-term incentives (both adjusted for inflation) in the post-IFRS 2 period (2006 to 2009). Companies were employing significantly more schemes 
TABLE 4: Descriptive statistics and analysis of variance on pre-recession and during-recession period.

\begin{tabular}{|c|c|c|c|c|c|}
\hline \multirow[t]{2}{*}{ Research variable } & \multicolumn{2}{|c|}{ Mean } & \multirow{2}{*}{$\begin{array}{l}F \text {-test } \\
\text { value }\end{array}$} & \multirow[t]{2}{*}{$p$} & \multirow[t]{2}{*}{ Interpretation } \\
\hline & $\begin{array}{l}\text { Pre-recession } \\
\text { (2006 to 2007) }\end{array}$ & $\begin{array}{l}\text { During-recession } \\
\text { (2008 to 2009) }\end{array}$ & & & \\
\hline \multicolumn{6}{|l|}{ General } \\
\hline Guaranteed pay (inflation adjusted)* & R3 729918 & R4 099444 & 2.3 & 0.13 & No significant change \\
\hline Short-term incentives (inflation adjusted) & R2 495017 & R2 621871 & 0.1 & 0.73 & No significant change \\
\hline Number of schemes employed & 1.07 & 1.38 & 10.6 & $<0.01$ & Significantly more schemes employed during the recession \\
\hline \multicolumn{6}{|l|}{ Share options } \\
\hline Number granted* & 270931 & 327654 & 0.4 & 0.56 & No significant change \\
\hline Number of closing balance* & 1596620 & 1478215 & 2.0 & 0.16 & No significant change \\
\hline \multicolumn{6}{|l|}{ SARs } \\
\hline Number granted & 234144 & 306153 & 0.1 & 0.79 & No significant change \\
\hline Number of closing balance & 572338 & 806319 & 1.6 & 0.23 & No significant change \\
\hline \multicolumn{6}{|l|}{ Share purchase plan } \\
\hline Number granted & 347927 & 7019 & 5.8 & 0.03 & Significantly fewer granted during recession \\
\hline \multicolumn{6}{|l|}{ Performance shares } \\
\hline Number granted & 0 & 186111 & N/A & N/A & Statistical tests not possible since no data in period before recession \\
\hline Number of closing balance & 0 & 246845 & $\mathrm{~N} / \mathrm{A}$ & N/A & - \\
\hline
\end{tabular}

*, A BoxCox transformation was applied to this data (as not normally distributed).

$\mathrm{N} / \mathrm{A}$, not applicable.

after the effective date of IFRS 2 - granting significantly more SARs, while the share options previously granted still had to complete their cycle of vesting and exercise (as is evident by the significant decrease in the closing balance of share options outstanding) in the post-IFRS 2 period.

\section{Comparing the period before and during the financial recession}

The period after the effective date of IFRS 2 (2006-2009) can be subdivided into the before-recession period (2006 and 2007) and the during-recession period (2008 and 2009). The reasons for studying the before- and during-recession periods are twofold. Firstly, there is a need to identify any changes brought about by the recession. Secondly, studying the before- and during-recession period can be used to validate whether a change was brought about by the effective date of IFRS 2. For a change in the characteristics of share-based remuneration to be attributable to the effective date of IFRS 2, the pre- and post-IFRS 2 period would need to differ significantly, and the before- and during-recession periods should not be significantly different (unaffected by recession).

Descriptive statistics (for each variable in the before- and during-recession period) can be observed in Table 4 . Furthermore, to evaluate whether the before- and duringperiod differed significantly, ANOVA tests were performed ( $F$-tests). A BoxCox transformation was applied where the data were not normally distributed, indicated by an asterisk $(*)$ in Table 4 . Some of the variables had too few data points, and could, therefore, not be analysed in this manner.

Table 4 shows that the increase in both guaranteed pay and short-term incentives in the during-recession period was not significant. It may be that the recession halted the increase in guaranteed pay and short-term incentives noted when evaluating the period before and after the effective date of IFRS 2. Significantly more schemes were being employed
TABLE 5: Differences between the pre- and during-recession period.

\begin{tabular}{lccl}
\hline Research variable & $\begin{array}{c}\text { Wald-test } \\
\text { value }\end{array}$ & $p$ & Interpretation \\
\hline $\begin{array}{l}\text { Whether a share option } \\
\text { scheme is used }\end{array}$ & 4.62 & $0.03 \begin{array}{l}\text { Share options schemes were less } \\
\text { likely to be in use during the recession }\end{array}$ \\
$\begin{array}{l}\text { Whether a share purchase } \\
\text { plan is used }\end{array}$ & 2.47 & 0.12 No significant difference \\
\begin{tabular}{l} 
Whether a SAR plan is used \\
\hline
\end{tabular} & 2.72 & 0.10 No significant difference \\
\hline
\end{tabular}

SAR, share-appreciation right.

during the recession, with performance shares only being added for the first time during the recession. The number of SARs granted and SARs outstanding at year-end, however, did not differ significantly before and during the recession.

In Table 5 a GEE test was performed to evaluate the likelihood of a certain scheme being employed before and during the recession. This evaluation indicated that share option plans were decreasing, as their exercise periods came to an end and were eliminated. Share-appreciation rights plans did not increase further during the recession.

The results concur with Avallone et al. (2014), namely that share options usage decreased during the recession. The type of share-based remuneration being granted was also shifting from share purchase plans to full quantum schemes (this switch to full quantum schemes was also reported in Rankin 2010). However, overall share-based remuneration usage was not decreasing in South Africa, which contradicts the findings of Rankin (2010).

\section{Discussion Outline of the results}

The objective of this study was to determine whether the implementation of IFRS 2 (in 2006) and the financial recession (of 2008/2009) affected the characteristics of South African executive share-based remuneration. It was found that the number schemes employed increased significantly after the effective date of IFRS 2, but then increased again during 
the recession. This seems to indicate new schemes being added after the effective date of IFRS 2 (SARs) and again during the recession (performance shares). This is in line with the findings from previous international research from developed economies and could be because of South African companies seeking to emulate their developed counterparts when it comes to executive share-based remuneration (Bruce et al. 2005). The homogeneity seen in the behaviour of South African companies could also be an indication of isomorphism (institutional theory): where the coercive (regulatory IFRS 2 requirements) and mimetic (companies imitating the market leaders) pressures from an external institution shape the business practices of companies.

Share option usage decreased after the effective date of IFRS 2 (closing balance numbers of share options were significantly lower), while it was less likely that a company would be employing a share option plan during the recession. Given the long vesting and exercise period typical of share option plans, this most likely points to gradual phasing out of share options, as fewer are granted and previously granted share option plans are wound up. It would seem that the effective date of IFRS 2 caused a shift between share options and SARs, because after the effective date of IFRS 2 it was significantly more likely for a company to be remunerating through SARs. The usage of SARs also did not change significantly before and during the recession. When examining the vesting conditions of the incentives being employed, the effective date of IFRS 2 did not seem to herald major changes in the vesting period being used ( $3-5$ years was common before and after the effective date of IFRS 2). The use of performance vesting conditions, however, increased during the period after IFRS 2 became effective, with TSR, EPS and share price targets as vesting conditions being commonly used.

Share purchase plans were unaffected by the effective date of IFRS 2, but were less likely to be granted during the recession. On the other hand, companies started granting performance shares during the recession. A possible reason for this change from share purchase plans to performance schemes during the recession could be the fact that no or little appreciation in share prices were occurring during the recession, which decreased the value of appreciation schemes in the eyes of executives and caused a shift from employing appreciation schemes to employing full quantum schemes, in line with findings from previous international research from developed countries (Rankin 2010).

\section{Practical implications}

The results of the study indicate that changing accounting regulations, as well as an economic downturn, does affect the characteristics of share-based remuneration paid to executives in South Africa (an emerging economy). This addresses a knowledge gap regarding the share-based remuneration practices and factors that influence these in emerging economies generally, and in South Africa specifically. In South Africa, it was clear by 2011 that share options had become less prevalent and SARs and performance shares have become more prevalent (Mavrodinov 2012), but the exact date of the change (and possible causes) had not been identified statistically before the present study.

This knowledge can be useful to shareholders who should evaluate trends regarding share-based remuneration (to appropriately assess their risks and benefits before approving such incentives at the annual general meeting). The fact that amended accounting requirements affect the characteristics of share-based remuneration is especially important in the light of the IASB recently reassessing IFRS 2 and considering major changes to the accounting treatment of equity-settled SBPs. Because the initial effective date of IFRS 2 brought about changes in the characteristics of share-based remuneration to executives, it is reasonable to expect that future changes may also have an impact on business practice in this regard. The IASB should be aware of this in their redrafting of IFRS 2 .

\section{Limitations of the study}

Limitations of the study include the limited sample selected, which cannot necessarily be generalised to the entire South African population nor other emerging economies, as well as the fact that only CEO remuneration was studied.

\section{Conclusion}

Institutional theory regarding executive remuneration proposes that it is important to consider the impact of environmental factors (such as changing accounting regulations and the financial recession) on the characteristics of share-based remuneration. Therefore, the objective of this study was to examine the characteristics of share-based remuneration to executive directors in South Africa, focusing on the period before and after the implementation of IFRS 2 , as well as before and during the recession. The sample selected comprised 28 companies listed on the JSE. Characteristics of the share-based remuneration paid to their CEOs for the period 2002-2009 were extracted from the IRESS financial database and corroborated by checking the AFS to ensure completeness and accuracy.

It is concluded that significant changes in the types of schemes employed occurred after the implementation of IFRS 2, as well as during the recession. Future research opportunities exist to extend this study to all executives, to all companies listed on the JSE as well as to other emerging economies. The impact of other environmental factors, such as the implementation of new corporate governance requirements, on the characteristics of executive share-based remuneration could also be evaluated.

\section{Acknowledgements}

The views expressed in this article are the authors' own and do not reflect the official position of the institution.

\section{Competing interests}

The authors declare that they have no financial or personal relationships that may have inappropriately influenced them in writing this article. 


\section{Authors' contribution}

N.W. was the project leader and responsible for experimental and project design. G.S. collected the data from IRESS and the annual financial statements and analysed the data.

\section{References}

Atan, R., Jasni, N.S. \& Shahwan, Y., 2010, 'The impact of IFRS 2 share-based payment on Malaysian companies', Review of Pacific Basin Financial Markets and Policies 13(3), 449-468. https://doi.org/10.1142/S0219091510002025

Avallone, F., Quagli, A. \& Ramassa, P., 2014, 'The effects of accounting treatment and financial crisis on the stock option plans of Italian companies', Economic and Business Review 16(1), 77-95.

Baeten, X., Balkin, D. \& Van den Berghe, L., 2011, 'Beyond agency theory: A threeparadigm approach to executive compensation', IUP Journal of Corporate paradigm approach to
Governance $10(4), 7-36$.

Balsam, S., O'Keefe, S. \& Wiedemer, M.M., 2007, 'Frontline reaction to FASB $123 R^{\prime}$ Journal of Accountancy 203(4), 54

Barontini, R., Bozzi, S., Ferrarini, G. \& Ungureanu, M.C., 2013, 'Directors' remuneration before and after the crisis: Measuring the impact of reforms in Europe', pape presented at the 23rd Annual Meeting of the American Tax and Economics Association, Vanderbilt University, Nashville, TN, May 2013, pp. 251-314. https:// doi.org/10.1017/СВ09781139629126.006

Baxter, R., 2008, 'The global economic crisis and its impact on South Africa and the country's mining industry', paper presented at the South African Reserve Bank Conference series on Challenges for Monetary Policy-makers in Emerging Markets, Bela-Bela, South Africa, October.

Bebchuk, L.A., Fried, J. \& Walker, D., 2002, 'Managerial power and rent extraction in the design of executive compensation', University of Chicago Law Review 69, 751-846. https://doi.org/10.2307/1600632

Bettis, J.C., Bizjak, J., Coles, J. \& Kalpathy, S., 2015, 'Performance-vesting provisions in executive compensation', viewed 25 April 2016, from http://cear.gsu.edu/ files/2014/03/WS_2014_0404_Performance-Vesting-Provisions-in-ExecutiveCompensation_BBCK_1-7-2014.pdf

Brown, L.D. \& Lee, Y., 2011, 'Changes in option-based compensation around the issuance of SFAS 123R', Journal of Business Finance and Accounting 38(9-10), 1053-1095. https://doi.org/10.1111/j.1468-5957.2011.02247.x

Bruce, A., Buck, T. \& Main, B.G.M., 2005, 'Top executive remuneration: A view from Europe', Journal of Management Studies 42(7), 1493-1506. https://doi.org/ 10.1111/j.1467-6486.2005.00553.x

Carter, M.E., Lynch, L.J. \& Tuna, I., 2007, 'The role of accounting in the design of CEO equity compensation', The Accounting Review 82(2), 327-357. https://doi.org/ 10.2308/accr.2007.82.2.327

Deephouse, D.L. \& Suchman, M., 2008, 'Legitimacy in organizational institutionalism' in R. Greenwood, C. Oliver, K. Sahlin \& R. Suddaby (eds.), The SAGE handbook of organizational institutionalism, pp. 49-77, Sage, London.

Deloitte, 2005, 'IFRS 2 - Employee share loan plans', viewed 17 May 2017, from https://www.iasplus.com/en/meeting-notes/ifrs-ic/not-added/2005/ifrs-2 employee-share-loan-plans

DiMaggio, P.J. \& Powell, W.W., 1983, 'The iron cage revisited: Institutional isomorphism and collective rationality in organizational fields', American Sociological Review 48, 147-160. https://doi.org/10.2307/2095101

Fisher, C. \& Wise, V., 2006, 'Share-based payments: Emerging issues', Occasional papers, vol. 13, pp. 1-18, Victoria University, Melbourne.

Giner, B. \& Arce, M., 2012, 'Lobbying on accounting standards: Evidence from IFRS on share-based payments', European Accounting Review 21(4), 655-691. https:// doi.org/10.1080/09638180.2012.701796

Hall, B.J. \& Murphy, K.J., 2003, 'The trouble with stock options', Working paper no. 9784, National Bureau of Economic Research (NBER), Cambridge, MA
Hoque, Z. (ed.), 2006, Methodological issues in accounting research: Theories and methods, Spiramus Press, London.

International Accounting Standards Board (IASB), n.d., 'History of IFRS 2', viewed 12 April 2017, from http://www.ifrs.org/Current-Projects/IASB-Projects/Sharebased-payments/Documents/IFRS-2-history.pdf

International Accounting Standards Board (IASB), 2004, IFRS 2 share based payments, IFRS Foundation, London.

International Accounting Standards Board (IASB), 2015a, 'Staff paper May 2015 Approach to research', viewed 13 April 2017, from http://www.ifrs.org/Meetings/ MeetingDocs/IASB/2015/May/AP15-IFRS\%202.pdf

International Accounting Standards Board (IASB), 2015b, 'Staff paper November 2015 Report on research so far', viewed 13 April 2017, from http://www.ifrs.org/ Meetings/MeetingDocs/IASB/2015/November/AP16-IFRS-2-Share-basedpayment.pdf

International Accounting Standards Board (IASB), 2016, 'Staff paper May 2016: Project update and agenda consultation feedback', viewed 13 April 2017, from http://www. ifrs.org/Meetings/MeetingDocs/IASB/2016/May/AP16-Share-based-Payment.pdf

Jensen, M.C. \& Murphy, K.J., 1990, 'CEO Incentives - It's not how much you pay, but how', Harvard Business Review 3(2), 138-153. https://doi.org/10.1111/j.1745 6622.1990.tb00207.x

Johannesburg Stock Exchange (JSE), 2017, 'JSE listing requirements', viewed 12 January 2017, from https://www.jse.co.za/content/JSERulesPoliciesandRegulationltems/ JSE\%20Listings\%20Requirements.pdf

Massie, K., Collier, D. \& Crotty, A., 2014, Executive salaries in South Africa: Who should have a say on pay?, Jacana Media, Auckland Park.

Mavrodinov, N., 2012, 'The changing landscape of long-term share-based compensation in South Africa', Unpublished Master's thesis, University of Cape Town, Cape Town.

Murphy, K.J., 2012, 'Executive compensation: Where we are, and how we got there', Working paper No. FBE 07.12, Marshall School of Business, Los Angeles, CA.

Pretorius, D. \& De Villiers, C., 2013, 'The effect of expensing share-based payments on basic earnings per share of South African listed companies', Meditari Accountancy Research 21(2), 178-190. https://doi.org/10.1108/MEDAR-03-2013-0006

Qu, X., Percy, M., Stewart, J. \& Hu, F., 2016, 'Executive stock options vesting conditions, corporate governance and CEO attributes: Evidence from Australia', Accounting and Finance 58(2), 503-533. https://doi.org/10.1111/acfi.12223

Rankin, M., 2010, 'Structure and level of remuneration across the top executive team' Australian Accounting Review 20(3), 241-255. https://doi.org/10.1111/j.1835 2561.2010.00097.x

Sahakiants, I. \& Festing, M., 2016, 'The use of executive share-based compensation in Poland: Investigating institutional and agency-based determinants in an emerging market', The International Journal of Human Resource Management 1-22. https://doi.org/10.1080/09585192.2016.1172652

Scholtz, H.E. \& Smit, A., 2012, 'Executive remuneration and company performance for South African companies listed on the Alternative Exchange (AltX)', Southern African Business Review 16(1), 22-38.

Suddaby, R., 2010, 'Challenges for institutional theory', Journal of Management Inquiry 19(1), 14-20. https://doi.org/10.1177/1056492609347564

Steenkamp, G. \& Wesson, N., 2018, 'Share-based incentives for South African CEOs: Trends 2002-2015', South African Journal of Accounting Research 32(1), 46-70. https://doi.org/10.1080/10291954.2017.1409869

Steyn, G.F., 2015, 'The relationship between CEO compensation and future share returns in South Africa', Unpublished Master's thesis, University of the Western Cape, Cape Town.

Urson, M., 2016, 'CEO pay ratios and company performance: A study of JSE-listed consumer goods and services companies', Unpublished Masters' thesis, University of Cape Town, Cape Town.

Wesson, N., Smit, E.v.d.M., Kidd, M. \& Hamman, W.D., 2017, 'Determinants of the choice between share repurchases and dividend payments', Research in International Business and Finance 45(C), 180-196. https://doi.org/10.1016/j. ribaf.2017.07.150 


\section{Appendix 1:}

TABLE 1-A1: List of companies in sample.

\begin{tabular}{|c|c|c|c|}
\hline Number & Name $\dagger$ & JSE sector $\dagger$ & Size rank \\
\hline 1 & Astral Foods & Food producers & Mid cap \\
\hline 2 & AVI & Food producers & Mid cap \\
\hline 3 & $\begin{array}{l}\text { Caxton \& CTP Publishers } \\
\text { \& Printers Limited }\end{array}$ & Media & Mid cap \\
\hline 4 & Clicks Group & Food and drug retailers & Mid cap \\
\hline 5 & $\begin{array}{l}\text { Compu-Clearing } \\
\text { Outsourcing }\end{array}$ & Software and computer services & Fledgling \\
\hline 6 & Digicore Holdings & Electronic and electrical equipment & Small cap \\
\hline 7 & EOH Holdings & Software and computer services & Small cap \\
\hline 8 & Excellerate Holdings & Support services & Fledgling \\
\hline 9 & Grindrod & Industrial transportation & Mid cap \\
\hline 10 & Iliad Africa & Support services & Small cap \\
\hline 11 & Imperial Holdings & Industrial transportation & Mid cap \\
\hline 12 & Invicta Holdings & Industrial engineering & Small cap \\
\hline 13 & Medi-Clinic International & Healthcare equipment and services & Mid cap \\
\hline 14 & Netcare & Healthcare equipment and services & Mid cap \\
\hline 15 & Paracon Holdings & Software and computer services & Fledgling \\
\hline 16 & Pick n Pay Stores & Food and drug retailers & Top 40 \\
\hline 17 & Pinnacle Holdings & Technology hardware and equipment & Fledgling \\
\hline 18 & Remgro & General industrials & Top 40 \\
\hline 19 & Sasol & Chemicals & Top 40 \\
\hline 20 & SecureData Holdings & Software and computer services & Fledgling \\
\hline 21 & Spur Corporation & Travel and leisure & Small cap \\
\hline 22 & Super Group & Industrial transportation & Small cap \\
\hline 23 & Telkom SA & Fixed line telecommunications & Top 40 \\
\hline 24 & The Bidvest Group & General industrials & Top 40 \\
\hline 25 & Transpaco & General industrials & Fledgling \\
\hline 26 & Truworths International & General retailers & Mid cap \\
\hline 27 & UCS Group & Software and computer services & Fledgling \\
\hline 28 & Woolworths Holdings & General retailers & Mid cap \\
\hline
\end{tabular}

JSE, Johannesburg Stock Exchange.

$\dagger$, Name and sector as at 31 December 2015; $\$$, Size rank as at 31 December 2009 (end date of the study). 